\title{
Original
}

\section{Actions of Cytokines in Caerulein-induced Acute Pancreatitis in Mice}

\author{
Katsuya Kitamura ${ }^{1)}$, Junichi NiIKawa ${ }^{1)}$, Tsunao Imamura ${ }^{1}$, \\ Akira TAKahashi $^{1}{ }^{1}$, Akitoshi IKegami $^{1}$, Hitoshi Yoshida ${ }^{1)}$, \\ Shigeki TanaKa ${ }^{1)}$, Tadakatsu Shimamura ${ }^{2)}$ and Keiji Mitamura ${ }^{1)}$
}

\begin{abstract}
The purpose of this study was to investigate the etiologic relationship between cytokines and the onset and progression of acute pancreatitis. Acute pancreatitis was induced in $\mathrm{BALB} / \mathrm{c}$ mice by administering six intraperitoneal injections of caerulein, each 1 hour apart. Measurements of pancreatic weight, plasma amylase, histopathologic scores, pancreatic myeloperoxidase (MPO), DNA, and protein were determined at 6, 12, 18, 24, 72, and $120 \mathrm{~h}$ after the first injection, and the levels of pancreatic tumor necrosis factor (TNF) $-\alpha$ and interleukin (IL) $-1 \beta$ were measured at 6,12 , and $18 \mathrm{~h}$. Some mice were treated with FR167653, a potent suppressant of TNF- $\alpha$ and IL-1 $\beta$ production, and measurements were taken $18 \mathrm{~h}$ after the first injection of caerulein to see if this drug could affect the progression of acute pancreatitis. Plasma amylase concentration was highest at $12 \mathrm{~h}$. The histologic severity and pancreatic MPO activity were highest at $18 \mathrm{~h}$. Pancreatic TNF- $\alpha$ was highest at $6 \mathrm{~h}$, and IL-1 $\beta$ was highest at $12 \mathrm{~h}$. Pancreatic weight, relative to DNA content, was significantly increased at $24 \mathrm{~h}$. Pancreatic protein levels, relative to DNA content, were significantly increased at 12 and $18 \mathrm{~h}$. The plasma amylase concentration, pancreatic MPO activity, pancreatic histologic scores, and the protein levels relative to DNA content, were significantly lower at 18 $h$, in mice treated with FR167653. Preventive administration of FR167653 ameliorated the caerulein-induced acute pancreatitis. TNF- $\alpha$ and IL-1 $\beta$ seem to be crucial factors in the onset and progression of acute pancreatitis, and blockade of these cytokines may attenuate the severity of acute pancreatitis.
\end{abstract}

Key words : tumor necrosis factor- $\alpha$, interleukin- $\beta$, acute pancreatitis, caerulein, FR167653

\section{Introduction}

Acute pancreatitis is a severe disease with high morbidity and mortality ${ }^{1)}$. Pathogenesis is believed to involve intracellular activation of digestive enzymes leading to pancreatic autodigestion, and multiple organ dysfunction ${ }^{2)}$. Pancreatic destruction also quickly induces an inflammatory reaction at the site of injury, leading to systemic inflammatory response syndrome (SIRS) ${ }^{2-6)}$. Recent evidence suggests that inflammatory cytokines such as tumor necrosis factor (TNF) $-\alpha$ and interleukin (IL) $-1 \beta$ are involved in the onset of acute pan-

\footnotetext{
1) Second Department of Internal Medicine, Showa University School of Medicine, 1-5-8 Hatanodai, Shinagawa-ku, Tokyo 142-8666, Japan.

${ }^{2)}$ Department of Microbiology and Immunology, Showa University School of Medicine.
} 
creatitis and the progression to SIRS and multiple organ dysfunction syndrome (MODS) ${ }^{6-8}$.

TNF- $\alpha$, which is produced mainly by activated monocytes and macrophages, mediates inflammation and the defense against bacterial and viral infection". Previous studies have shown that acinar cells and macrophages produce TNF- $\alpha$ during the development of acute pancreatitis and that TNF- $\alpha$ up-regulates the expression of intercellular adhesion molecules (ICAM). IL-1 $\beta$ also plays an important role in host responses to inflammation and infection. Pathophysiologic involvement of IL-1 $\beta$ has been demonstrated in the acute-phase response of inflammation, in the host defense against bacterial and viral infection, and in the activation of the immune system ${ }^{10)}$. Moreover, TNF- $\alpha$, IL-1 $\beta$, and IL-6, are released by activated macrophages that have been primed by chemoattractant cytokine receptors (CCRs), and they enhance synthesis of acute-phase proteins and activate neutrophils and lymphocytes ${ }^{11)}$.

Knockout (KO) mice deficient in TNF type 1 receptors and IL-1 type 1 receptors experience less severe acute pancreatitis compared with wild-type mice ${ }^{12-14)}$. Further, TNF and IL-1 receptor antagonists and anti-TNF- $\alpha$ antibodies can improve survival and reduce the adverse sequelae of acute pancreatitis ${ }^{15-20)}$. These findings suggest that the inhibition of both TNF- $\alpha$ and IL-1 $\beta$ can improve the outcome of acute pancreatitis. To test this hypothesis, we used a new drug, FR167653, which is a potent suppressant of TNF- $\alpha$ and IL-1 $\beta$ production that reportedly exerts a protective effect on monocytes ${ }^{21,22)}$. We investigated whether TNF- $\alpha$ and IL-1 $\beta$ play an important role in the onset and progression of caerulein-induced acute pancreatitis in mice.

\section{Materials and Methods}

\section{Animals}

Male BALB/c mice 10 to 13 week-old, weighing 22 to $27 \mathrm{~g}$, were purchased from Saitama Experimental Animal Supply (Suginomachi, Saitama, Japan). All experimental procedures were approved by the committee for Institutional Animal Care and Use, Showa University.

\section{Chemicals}

Chemicals were purchased from the following sources: caerulein, from Sigma (St. Louis, MO, USA); human neutrophil myeloperoxidase (MPO), from Athens Research and Technology (Athens, GA, USA); hexadecyltrimethyl ammonium bromide (HETAB) and o-dianiside dihydrochloride, from Sigma. FR167653, a low molecular weight pyrazolotriazine derivative (1-[7-(4-fluorophenyl)-1,2,3,4-tetrahydro-8-(4-pyridyl) pyrazolo [5, 1-c] [1, 2,4] triazine-2-yl]2-phenylethanedione sulfate monohydrate), was donated by the Fujisawa Pharmaceutical Co., Ltd.(Osaka, Japan) ${ }^{21,22)}$.

\section{Experimental protocol}

All mice $(n=46)$ were fasted for 8 to $10 \mathrm{~h}$ and studied in the conscious state. Acute pancreatitis was induced by intraperitioneal injection of caerulein $(50 \mu \mathrm{g} / \mathrm{kg}$, six injections at $1 \mathrm{~h}$ intervals) using a modification of the technique of Niederau et $a l^{1}$. Mice were sacrificed $6(n=6), 12(n=6), 18(n=6), 24(n=5), 72(n=5)$, and $120 h(n=6)$ after the first injection of caerulein, following anesthesia with sodium pentobarbital. To suppress the actions of both TNF- $\alpha$ and IL- $1 \beta$ in caerulein-induced pancreatitis, FR167653 was intraperitoneally injected into mice $(\mathrm{n}=6)(37.5 \mathrm{mg} / \mathrm{kg}, 4 \text { injections at } 3 \mathrm{~h} \text { intervals })^{23)}$, 
beginning $3.5 \mathrm{~h}$ before the first injection of caerulein. An equal volume of saline was administered to control mice $(n=6)$ instead of FR167653. Mice were sacrificed $18 \mathrm{~h}$ after the first injection of caerulein.

\section{Assays and preparation of tissue extract}

Blood samples were collected by cardiac puncture, followed by determination of plasma amylase, using the Neo-Amylase Test (Daiichi Pure Chemical, Tokyo, Japan). Pancreatic tissue was removed rapidly from individual mice and weighed, and 100 to $150 \mathrm{mg}$ of the pancreatic tissue was stored at $-80^{\circ} \mathrm{C}$ for subsequent measurement of pancreatic MPO activity, protein and DNA content. The remaining tissue was fixed with $20 \%$ phosphatebuffered formalin at room temperature, in preparation for light microscopic examination.

\section{Histologic examination}

A portion of fixed pancreatic tissue was embedded in paraffin and stained with hematoxylin and eosin (HE), for histologic analysis. Histologic alterations, including vacuolation within acinar cells, inflammatory cell infiltration, and acinar cell necrosis, were evaluated in a blind manner. Using a modified system of Niederau et $a l^{1}$, scores were classified into one of five grades, according to the number of affected cells per field at $\times 200$ magnification. Scores were graded as follows: 0 , absent; $1,<5 \% ; 2,5$ to $25 \% ; 3,25$ to $50 \% ; 4,>50 \%$. The scores were obtained by averaging four visual fields for each sample.

\section{Pancreatic MPO assay}

MPO activity is considered a quantitative index of tissue neutrophil content. MPO was extracted by suspending pancreatic tissue homogenate in $20 \mathrm{mM}$ potassium phosphate buffer containing $0.5 \%$ HETAB, followed by freeze-thawing three times, and centrifugation at $15,000 \mathrm{rpm}$ for $30 \mathrm{~min}$. The supernatant was then assayed, using a modification of the technique of Bradley et $a l^{24)}$. MPO activity was expressed as units per gram of wet pancreatic tissue.

\section{Pancreatic weight and protein level relative to DNA content}

Frozen pancreatic tissue samples were homogenized in distilled water on ice, using a Polytron homogenizer. Pancreatic DNA and protein contents were determined by Burton's and Lowry's methods ${ }^{25-28)}$, respectively. Pancreatic weight and protein level were expressed relative to DNA content, as milligrams of tissue per microgram of DNA, and micrograms of protein per microgram of DNA, respectively.

\section{Pancreatic cytokine concentrations}

Frozen pancreatic tissue samples were homogenized in $0.9 \% \mathrm{NaCl}$ on ice, using a Polytron homogenizer, followed by centrifugation at $15,000 \mathrm{rpm}$ for $10 \mathrm{~min}$. Using the supernatant, pancreatic TNF- $\alpha$ and IL-1 $\beta$ concentrations were measured with enzymelinked immunosorbent assay (ELISA) kits (BioSource International, Camarillo, CA, USA). Concentrations were expressed as picograms per gram of wet pancreatic tissue.

\section{Statistical analysis}

Results are expressed as the mean \pm SD. Data were analyzed using one-way analysis of 
variance (ANOVA), followed by Scheffe's F test. Statistical comparison between the two groups was made using the unpaired t-test. All $P$ values were two-tailed, and $P$ values less than 0.05 were considered statistically significant.

\section{Results}

Body weight and pancreatic tissue wet weight

There was no significant difference in body weight during the experimental period. Pancreatic tissue wet weight was significantly increased at 6,12 , and $18 \mathrm{~h}$ after the first injection of caerulein $(P<0.05)$, compared with the pretreatment value (Fig. 1).

\section{Plasma amylase concentration}

Twelve hours after the first injection of caerulein, plasma amylase concentrations were significantly increased $(P<0.05)$ in comparison with the pretreatment values. Values gradually decreased thereafter (Fig. 2 ).

\section{Histologic findings}

Six hours after caerulein injection, pancreatic tissue showed hypertrophy of acinar cells with occasional vacuolation. Inflammatory cell infiltration and acinar cell necrosis, as well as vacuolation, were observed at 12 and $18 \mathrm{~h}$. Interstitial edema and hemorrhage were not prominent. Vacuolation and inflammatory cell infiltration subsided by $72 \mathrm{~h}$. Acinar cell mitoses were observed at $120 \mathrm{~h}$ (Fig. 3).

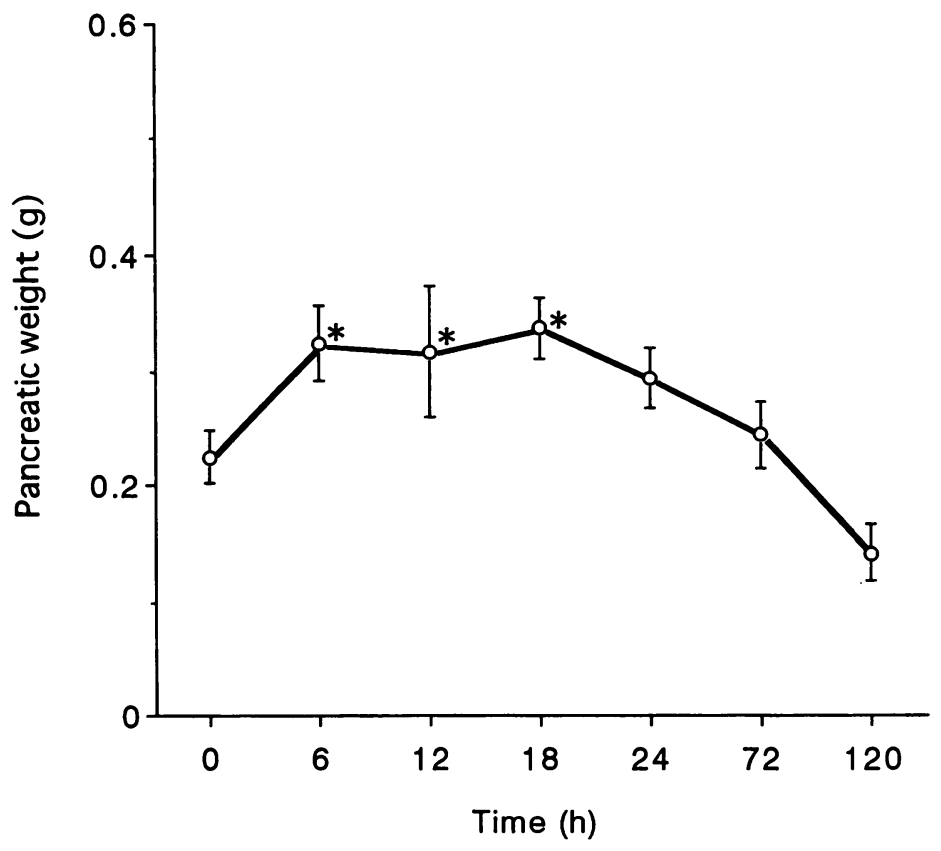

Fig. 1. Time course of pancreatic weight in mice with caerulein-induced acute pancreatitis.

Pancreatic weight was significantly increased at 6,12 , and $18 \mathrm{~h}$ after caerulein injection.

${ }^{*} P<0.05$ : Significant difference versus pretreatment value. 


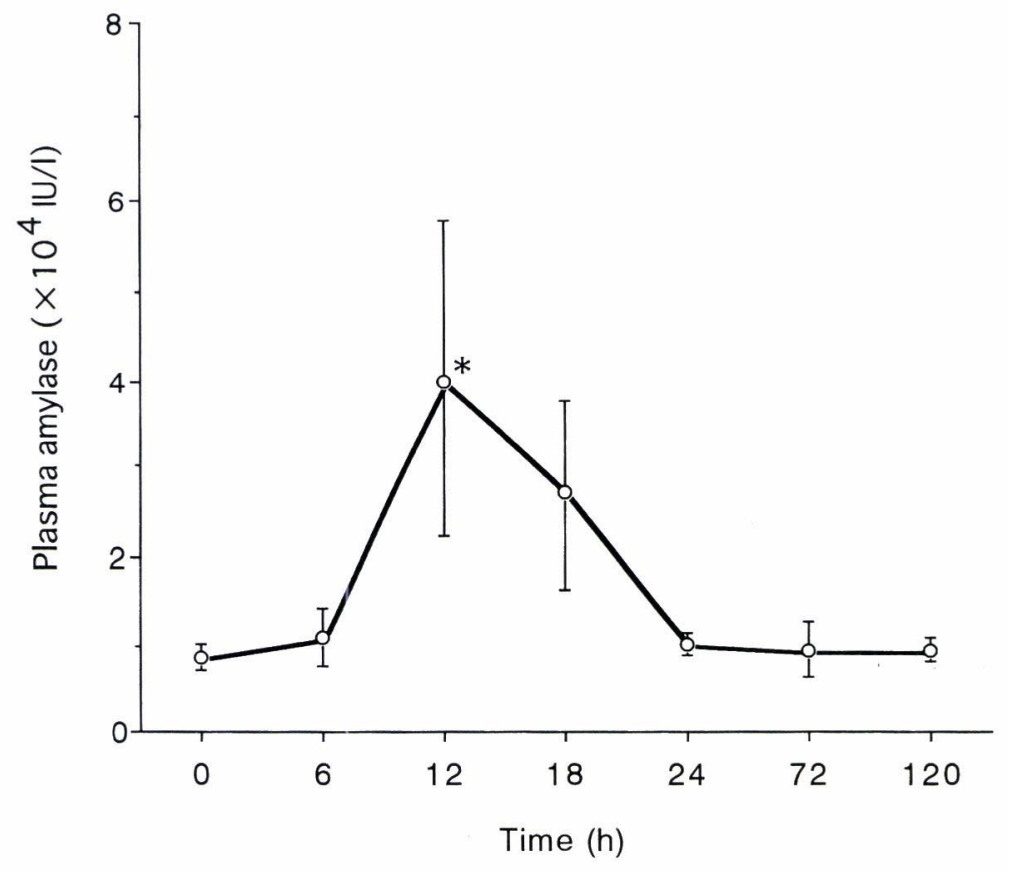

Fig. 2. Time course of plasma amylase concentration.

After caerulein injection, plasma amylase concentrations peaked at $12 \mathrm{~h}$, and then decreased gradually.

${ }^{*} P<0.05$ : Significant difference versus pretreatment value.
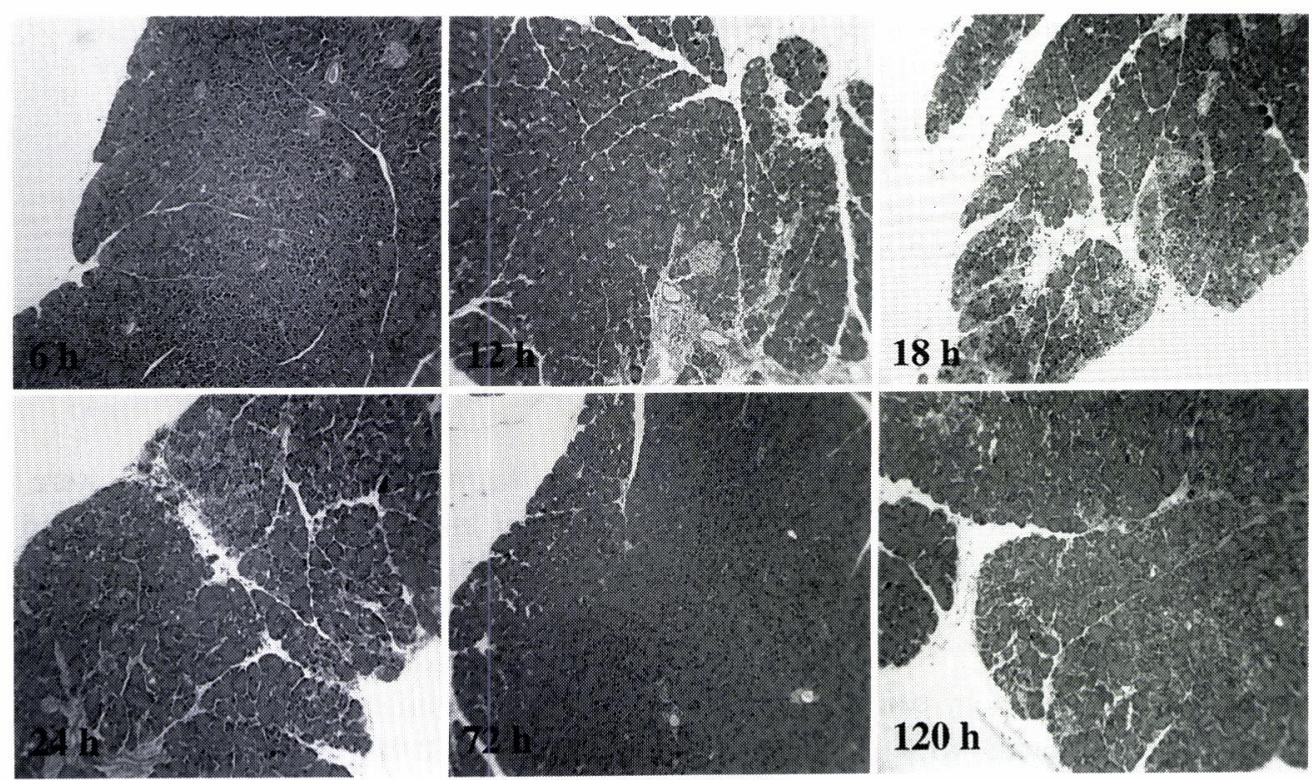

Fig. 3. Time course of histologic alterations (hematoxylin and eosin; original magnification, $\times 200$ ). After caerulein injection, vacuolation is observed in some acinar cells at $6 \mathrm{~h}$. Inflammatory cell infiltration and acinar cell necrosis are especially marked at 12 and $18 \mathrm{~h}$. Vacuolation and inflammatory cell infiltration subside at $72 \mathrm{~h}$. 

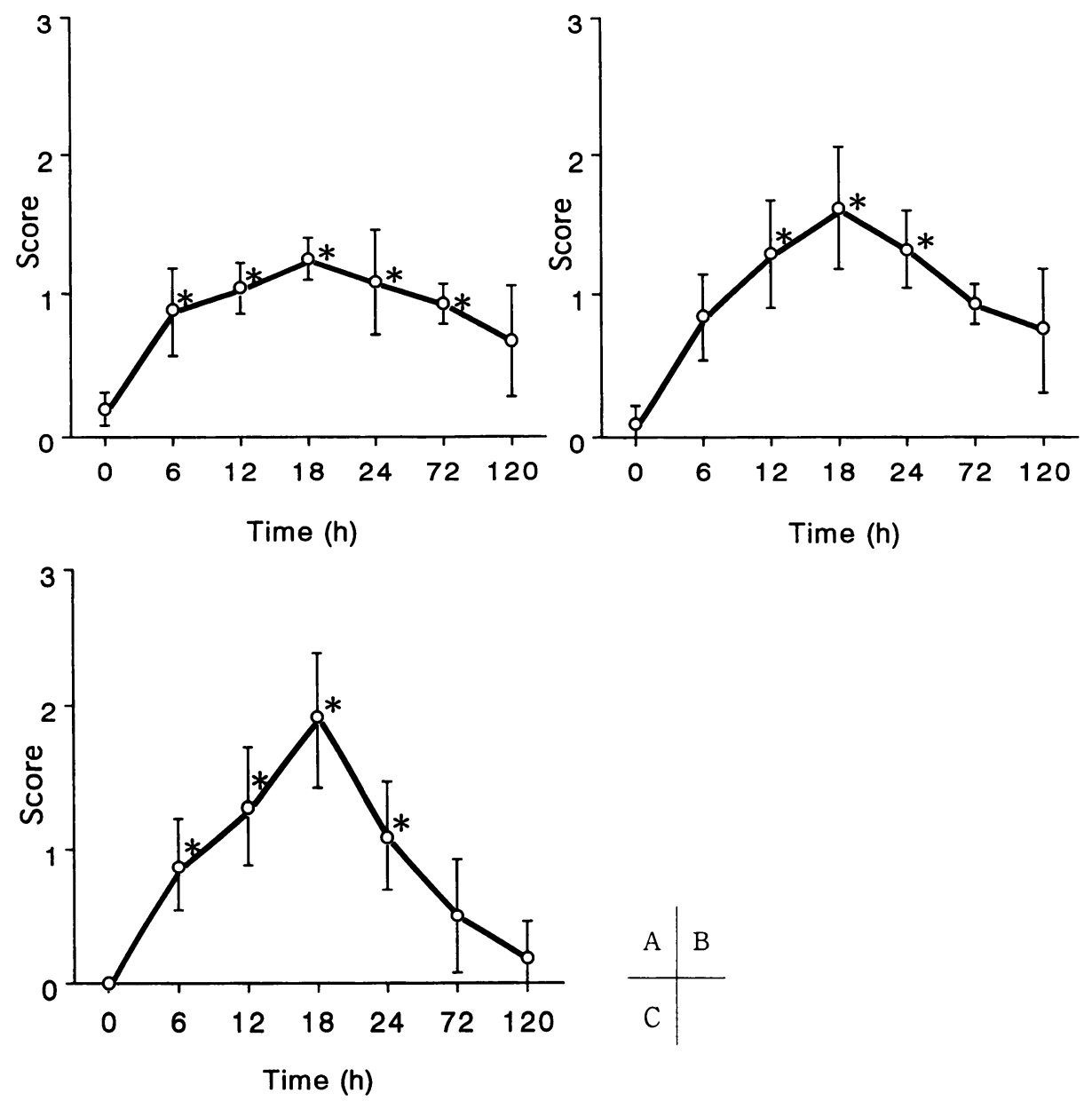

Fig. 4. Histologic scores.

A : Vacuole formation within acinar cells. B : Inflammatory cell infiltration. C: Necrosis of acinar cells. All histologic scores increased gradually after caerulein injection, and peaked at $18 \mathrm{~h}$.

${ }^{*} P<0.05$ : Significant difference versus pretreatment value.

\section{Histologic evaluation}

Pancreatic histologic scores for vacuolaion, inflammation and necrosis were also significantly increased at 12,18 , and $24 \mathrm{~h}$ after caerulein injection $(P<0.05)$, compared with the pretreatment values, and all scores were highest at $18 \mathrm{~h}$ (Fig. 4).

\section{Pancreatic MPO activity}

After caerulein injection, pancreatic MPO activity was significantly increased at $6,12,18$, 24 , and $72 \mathrm{~h}$, compared with the pretreatment value $(P<0.05)$, and was highest at $18 \mathrm{~h}$ (Fig. 5).

Pancreatic weight and protein level relative to DNA content

After caerulein injection, pancreatic weight relative to DNA content was significantly 


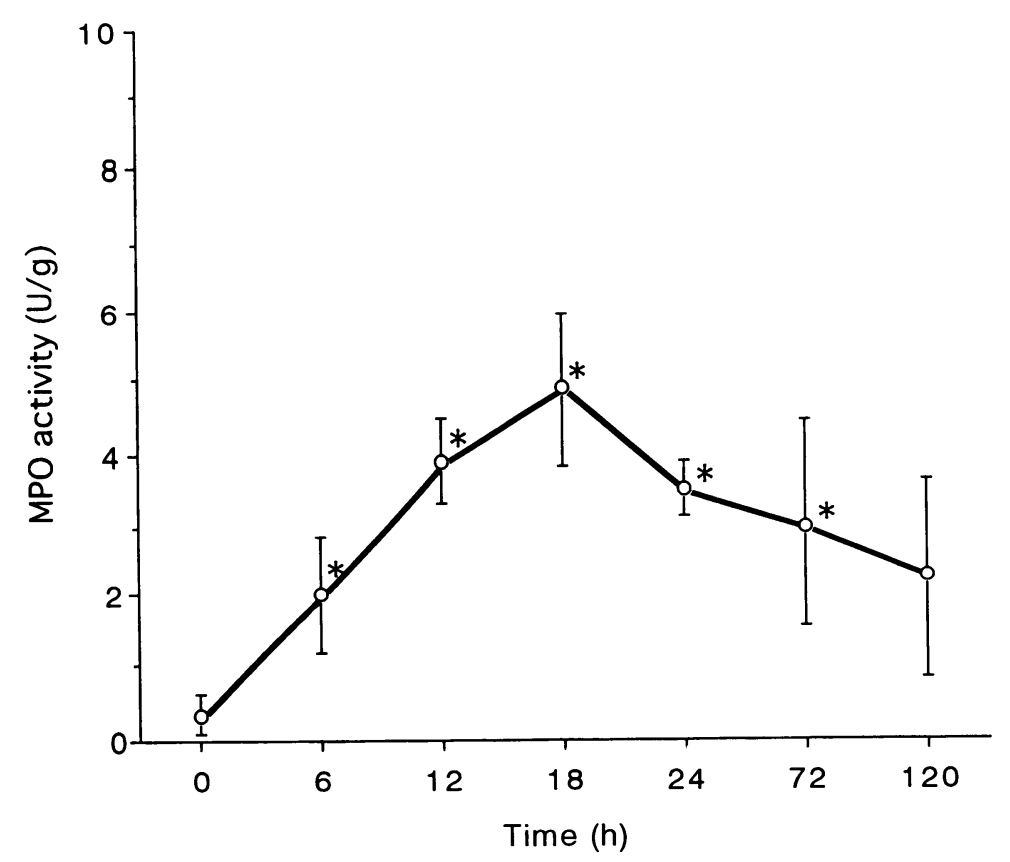

Fig. 5. Time course of pancreatic MPO activity. After caerulein injection, pancreatic MPO activity was significantly increased at $6,12,18,24$, and $72 \mathrm{~h}$, peaking at $18 \mathrm{~h}$.

${ }^{*} P<0.05$ : Significant difference versus pretreatment value.

increased at $24 \mathrm{~h}$, compared with the pretreatment values (Fig. 6). Pancreatic protein levels, relative to DNA content, were significantly increased at 12 and $18 \mathrm{~h}(P<0.05)$ (Fig. 7).

\section{Pancreatic cytokine concentrations}

After caerulein injection, pancreatic TNF- $\alpha$ concentrations were highest at $6 \mathrm{~h}$, and IL$1 \beta$ concentrations were highest at $12 \mathrm{~h}$ (Fig. 8).

\section{Effect of FR167653 on caerulein-induced acute pancreatitis}

In mice treated with FR167653, the degree of vacuolation, inflammatory cell infiltration, and acinar cell necrosis, was reduced at $18 \mathrm{~h}$ compared with control mice (Fig. 9). Plasma amylase concentration, pancreatic MPO activity, and all pancreatic histologic scores were significantly decreased at $18 \mathrm{~h}$ in mice treated with FR167653 (Figs. 10, 11), but no significant changes were observed in pancreatic weight relative to DNA content. On the other hand, pancreatic protein levels, relative to DNA content, were significantly decreased at $18 \mathrm{~h}$ in mice treated with FR167653 (Fig. 12).

\section{Discussion}

Intraperitoneal injection of high doses of caerulein causes acute necrotizing pancreatitis in mice ${ }^{1)}$. Norman reported that a number of inflammatory mediators are produced locally and systemically in the development of acute pancreatitis in animal models and humans, as 


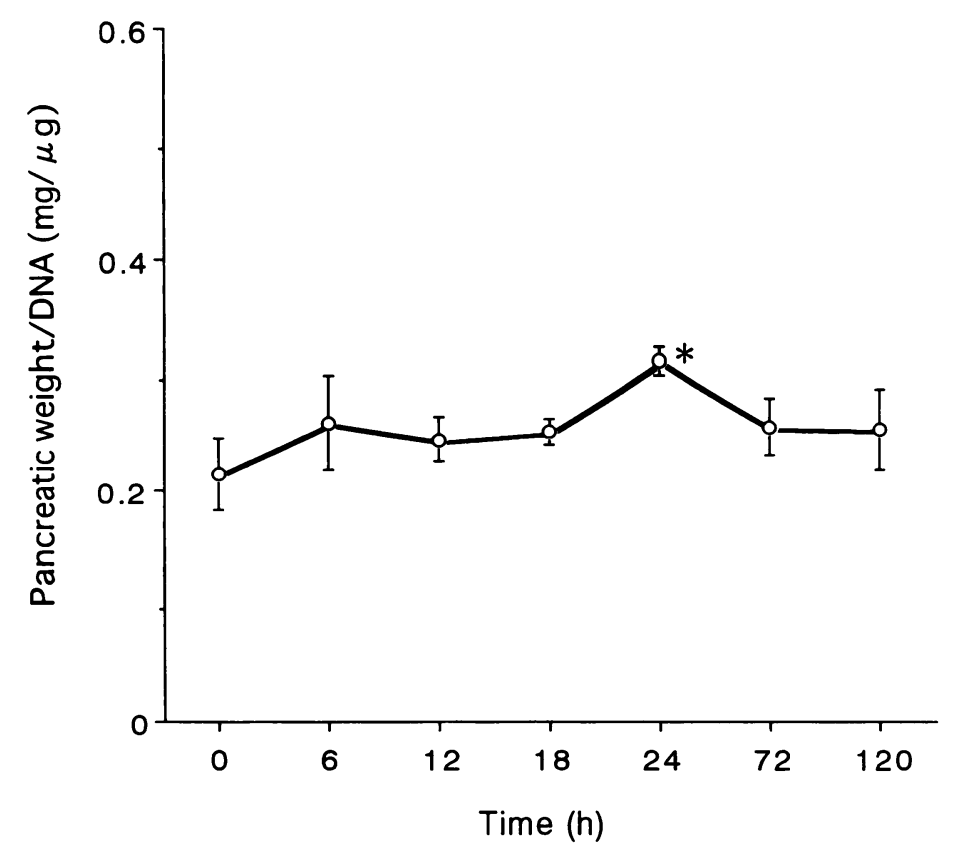

Fig. 6. Time course of pancreatic weight relative to DNA content. Pancreatic weight relative to DNA content was significantly increased at $18 \mathrm{~h}$. ${ }^{*} P<0.05$ : Significant difference versus pretreatment value.



Fig. 7. Time course of pancreatic protein level relative to DNA content. After caerulein injection, the pancreatic protein level relative to DNA content was significantly increased at 12 and $18 \mathrm{~h}$.

${ }^{*} P<0.05$ : Significant difference versus pretreatment value. 


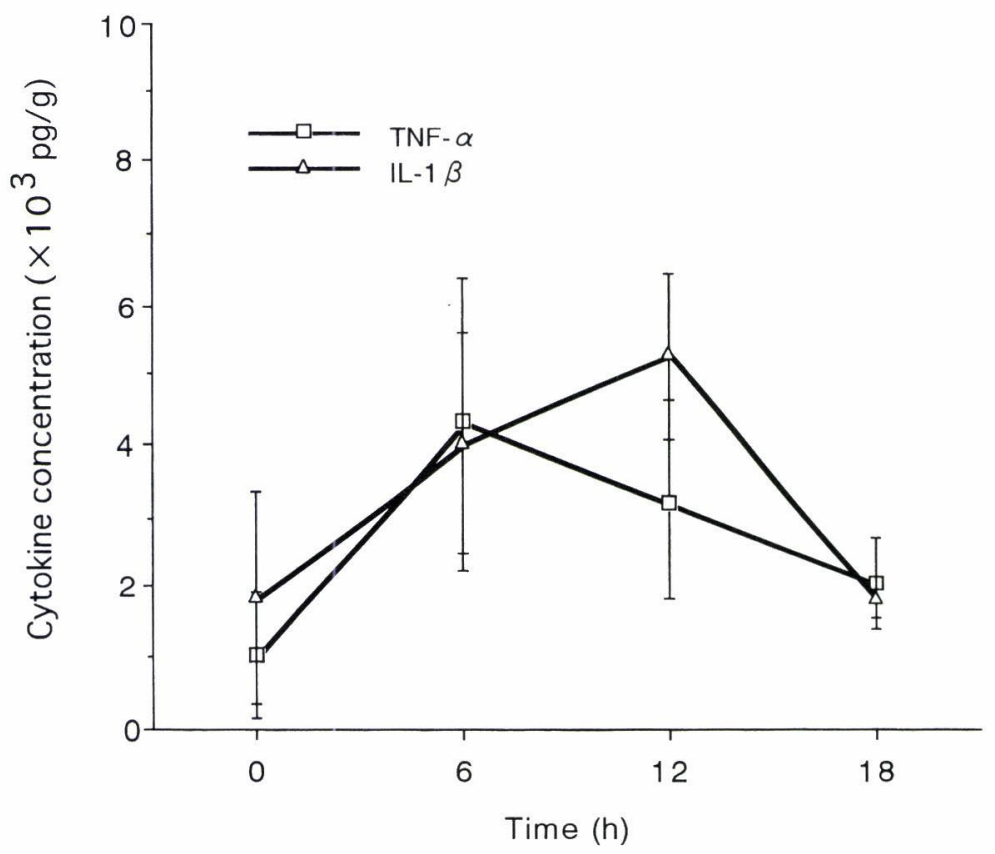

Fig. 8. Time course of pancreatic cytokine concentrations.

After caerulein injection, the pancreatic TNF- $\alpha$ concentration was highest at $6 \mathrm{~h}$, and the IL-1 $\beta$ concentration was highest at $12 \mathrm{~h}$.

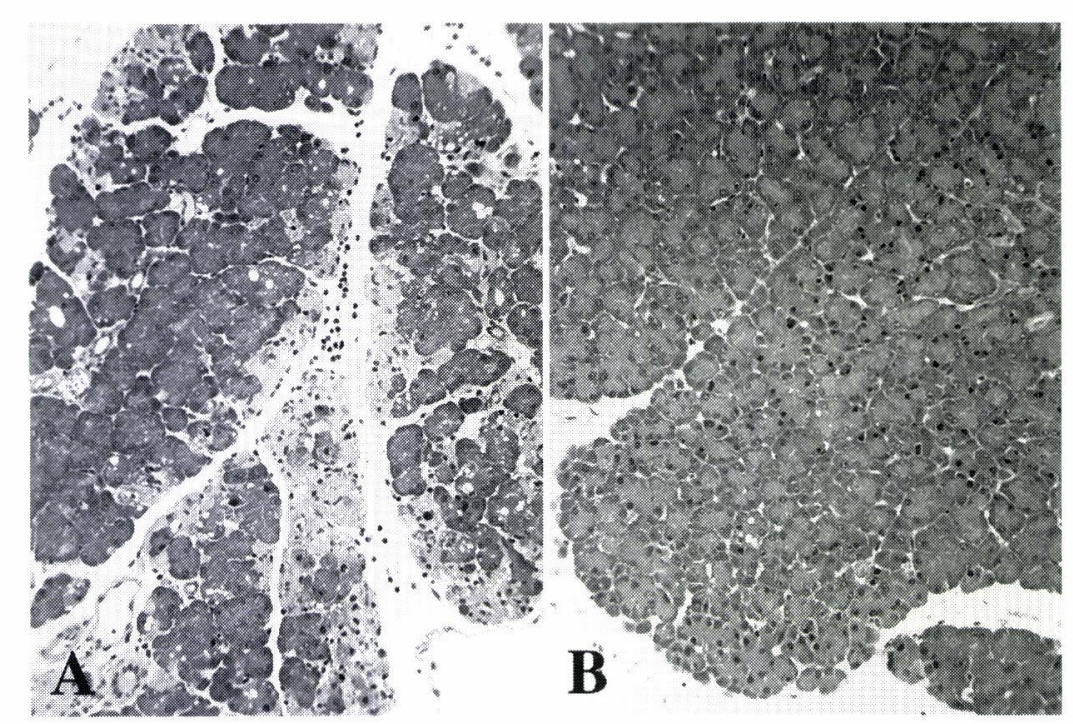

Fig. 9. Effect of FR167653 on pancreatic tissue at $18 \mathrm{~h}$ (hematoxylin and eosin; original magnification, $\times 400)$.

(A) After caerulein injection, vacuolation, inflammatory cell infiltration, and acinar cell necrosis are observed in control mice.

(B) These changes are reduced in mice treated with FR167653. 

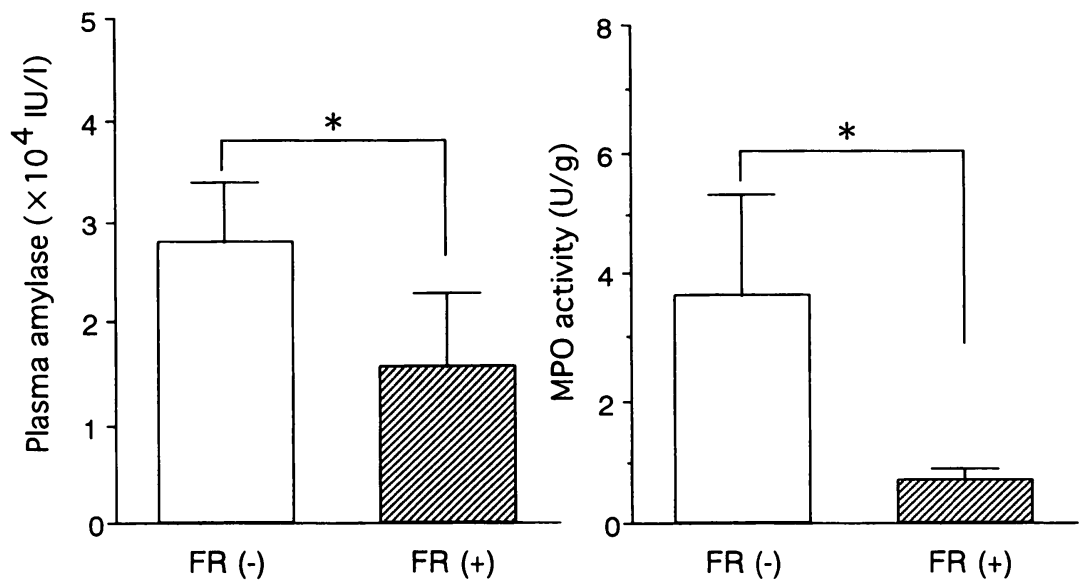

Fig. 10. Effect of FR167653 on plasma amylase concentrations and pancreatic MPO activity at $18 \mathrm{~h}$.

Plasma amylase concentrations and pancreatic MPO activity were significantly lower in mice treated with FR 167653. ${ }^{*} P<0.05$



FR (-)
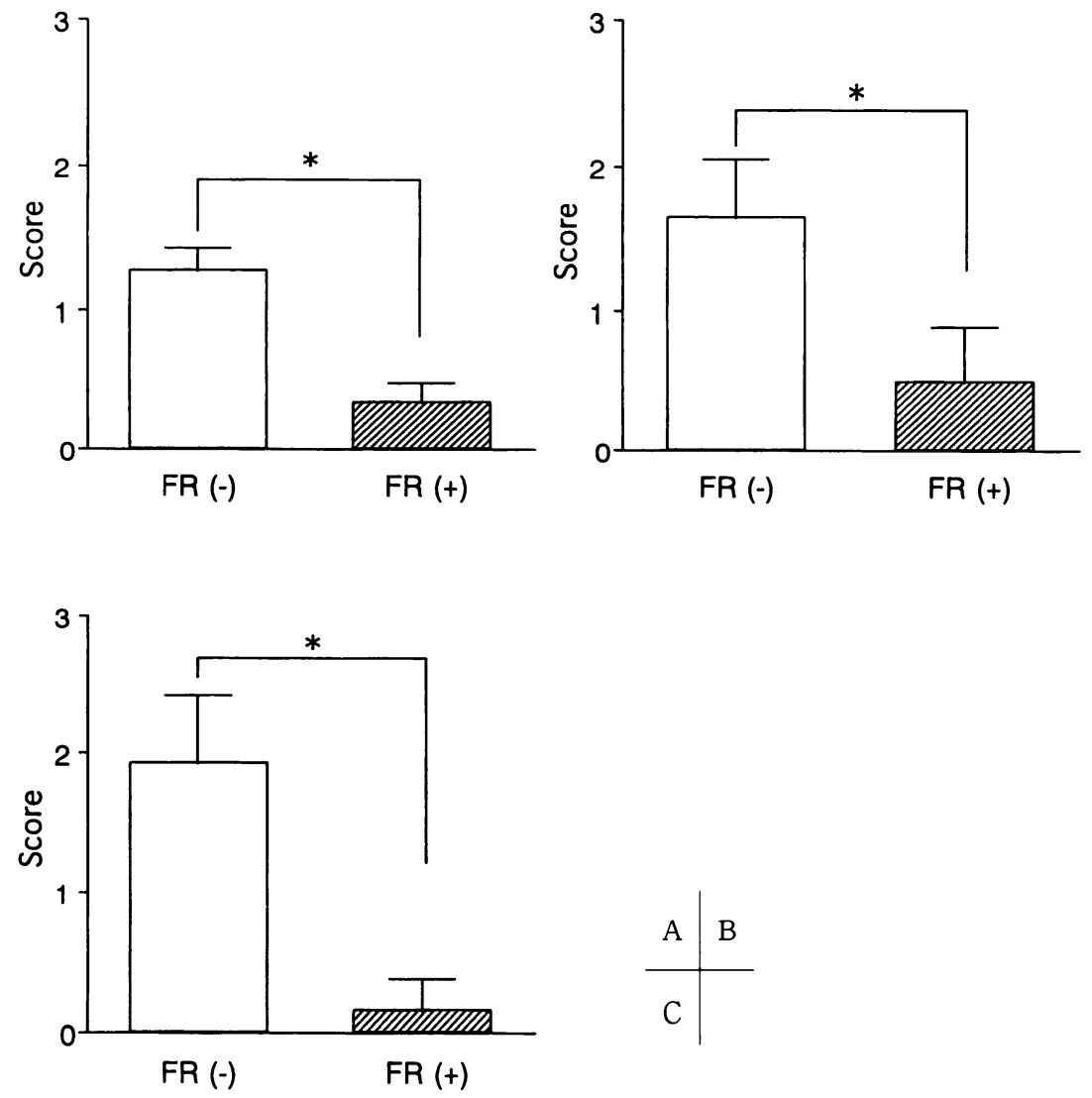

Fig. 11. Pancreatic histologic scores at $18 \mathrm{~h}$.

A : Vacuole formation within acinar cells. B : Inflammatory cell infiltration. C: Necrosis of acinar cells. All histologic scores were significantly decreased in mice treated with FR167653. ${ }^{*} P<0.05$ 

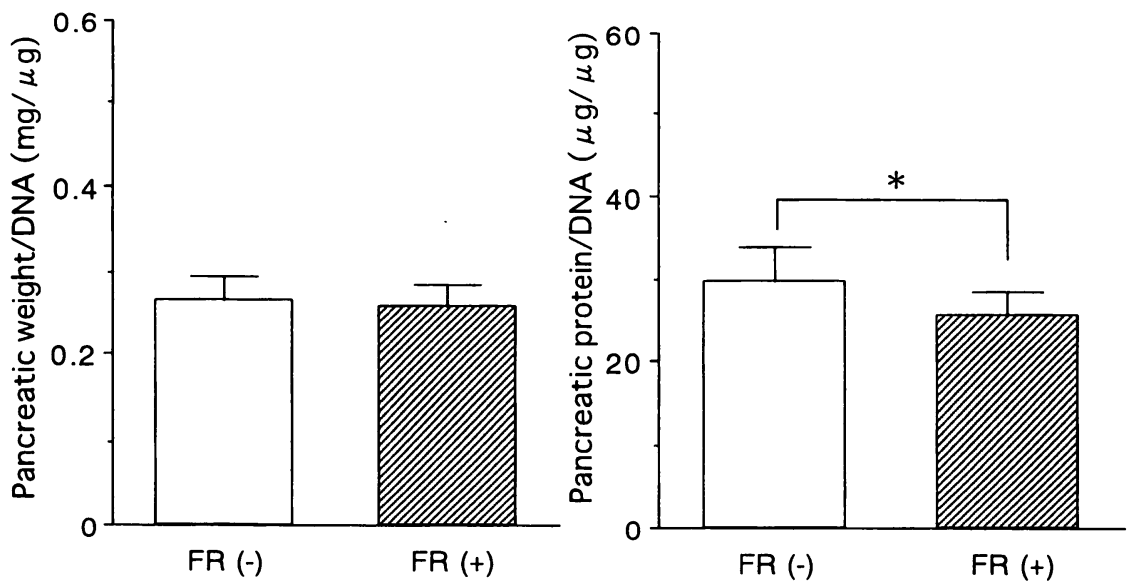

Fig. 12. Effect of FR167653 on pancreatic weight and protein level relative to DNA content at $18 \mathrm{~h}$.

Pancreatic weight relative to DNA content in mice treated with FR167653 was similar to control mice. Pancreatic protein levels relative to DNA content were significantly lower in mice treated with FR167653. ${ }^{*} P<0.05$

a rapidly developing cascade in which the various mediators amplified one another ${ }^{2}$. Norman also suggested that TNF- $\alpha$ and IL-1 have the ability to induce production of almost all of the other mediators, and that they are important in both local pancreatic injury and systemic manifestations.

We used caerulein to induce acute pancreatitis in mice $(50 \mu \mathrm{g} / \mathrm{kg}$, six injections $)$ and sacrificed them at $6,9,12,18,24,72$ and $120 \mathrm{~h}$ after the first injection. The plasma amylase concentration was highest at $12 \mathrm{~h}$, and the pancreatic MPO activity was highest at $18 \mathrm{~h}$. The major histologic change in caerulein-induced acute pancreatitis was not interstitial edema, but rather, was interstitial inflammation and acinar cell necrosis. The most severe changes were apparent at $18 \mathrm{~h}$ after caerulein injection. Serum amylase concentration is a reliable indicator of histologic severity that maps the course of the inflammatory process in caerulein-induced acute necrotizing pancreatitis ${ }^{1)}$, and our studies confirmed this relationship.

Following caerulein injection, pancreatic TNF- $\alpha$ concentrations were highest at $6 \mathrm{~h}$, and IL-1 $\beta$ concentrations were highest at $12 \mathrm{~h}$. Thus, TNF- $\alpha$, which is produced by monocytes and macrophages, appears to be upstream in the cyokine cascade compared with IL-1. In addition to pancreatic tissue assays for TNF- $\alpha$ and IL- $\beta$, we performed assays for these cytokines in blood, but no mice showed measurable amounts (data not shown). Therefore, acute pancreatitis in this early-stage model showed a local but not a systemic inflammatory response.

Pancreatic acinar cells tended to be enlarged by $6 \mathrm{~h}$ following the first caerulein injection, therefore, pancreatic tissue weight was significantly increased at $6,12,18 \mathrm{~h}$ and the pancreatic protein levels, relative to DNA content, were significantly increased at 12 and 18 h.

Our studies showed that pancreatic injury was most severe at $18 \mathrm{~h}$ after the first caerulein injection, while levels of TNF- $\alpha$ and IL-1 $\beta$ were found to peak much earlier. We therefore hypothesize that these cytokines are important in the development of pancreatic 
destruction in early stages of acute pancreatitis. FR167653 is a potent anti-inflammatory drug that suppresses TNF- $\alpha$ and IL-1 $\beta$ production in models of both disseminated intravascular coagulation and endotoxin-induced shock $^{21,22)}$. FR167653 was injected intraperitoneally ( 4 times at $3 \mathrm{~h}$ intervals, for a total of $150 \mathrm{mg} / \mathrm{kg} / \mathrm{day})^{23)}$, beginning $3.5 \mathrm{~h}$ before the first injection of caerulein. In the pancreatic tissue of mice treated with FR167653, vacuolation, inflammatory cell infiltration, and acinar cell necrosis had subsided by $18 \mathrm{~h}$. Plasma amylase concentration, pancreatic MPO activity, pancreatic histologic scores, and pancreatic protein level relative to DNA content, were significantly lower in mice treated with FR167653. The severity of acute pancreatitis was markedly reduced with pre-treatment of FR167653.

In conclusion, TNF- $\alpha$ and IL-1 $\beta$ appear to be pathogenetic factors in the early stage of acute pancreatitis. Therapeutic blockade of these cytokines in the presentation of disease may attenuate its severity and reduce the risk of a serious systemic response. FR167653 may prove to be clinically useful for treating patients with acute pancreatitis, however further studies are needed to determine whether blockade of inflammatory cytokines can affect the clinical course of acute pancreatitis.

\section{References}

1) Niederau C, Ferrell LD and Grendell $\mathbf{J H}$ : Caerulein-induced acute necrotizing pancreatitis in mice : protective effects of proglumide, benzotript, and secretin. Gastroenterology 88 : 1192-1204 (1985)

2) Norman $J:$ The role of cytokines in the pathogenesis of acute pancreatitis. Am J Surg 175: 76-83 (1988)

3) Wilson PG, Manji M and Neoptolemos JP : Acute pancreatitis as a model of sepsis. J Antimicrob Chemother 41(Supple A): 51-63 (1998)

4) Winslet M, Hall C, London NJM and Neoptolemos JP: Relation of diagnostic serum amylase levels to aetiology and severity of acute pancreatitis. Gut 33 : 982-986 (1992)

5) Neoptolemos JP, Raraty $M$ and Finch $M$ and Sutton $R$ : Acute pancreatitis: the substantial human and financial costs. Gut $42: 886-891$ (1998)

6) Bhatia M, Brady M, Shokuhi S, Christmas S, Neoptolemos JP and Slavin J : Inflammatory mediators in acute pancreatitis. J Pathol 190 : 117-125 (2000)

7) Norman J, Fink $G$ and Franz $\mathbf{M}$ : Acute pancreatitis induces intrapancreatic tumor necrosis factor gene expression. Arch Surg 130 : 966-970 (1995)

8) Norman JG, Fink GW, Denham W, Yang J, Carter G, Sexton C, Falkner J, Gower WR and Franz MG: Tissue-specific cytokine production during experimental acute pancreatitis. A probable mechanism for distant organ dysfunction. Dig Dis Sci $42: 1783-1788$ (1997)

9) Taniguchi T, Takata M, Ikeda A, Momotani E and Sekikawa K: Failure of germinal center formation and impairment of response to endotoxin in tumor necrosis factor $\alpha$-deficient mice. Lab Invest 77 : 647-658 (1997)

10) Horai R, Asano M, Sudo K, Kanuka H, Suzuki M, Nishihara M, Takahashi $M$ and Iwakura Y : Production of mice deficient in genes for interleukin (IL) $-1 \alpha$, IL-1 $\beta$, IL-1 $\alpha / \beta$, and IL-1 receptor antagonist shows that IL- $\beta$ is crucial in turpentine-induced fever development and glucocorticoid secretion. J Exp Med 187 : 14631475 (1998)

11) Pastor CM and Frossard J-L : Are genetically modified mice useful for the understanding of acute pancreatitis? FASEB J $15: 893-897$ (2001)

12) Denham W, Yang J and Norman J. Evidence for an unknown component of pancreatic ascites that induces adult respiratory distress syndrome through an interleukin-1 and tumor necrosis factor-dependent mechanism. Surgery 122 : 295-302 (1997)

13) Denham W, Yang J, Fink G, Denham D, Carter G, Ward K and Norman J : Gene targeting demonstrates additive detrimental effects of interleukin-1 and tumor necrosis factor during pancreatitis. Gastroenterology 113 : 1741-1746 (1997)

14) Norman JG, Fink G, Franz M, Guffey J, Carter G, Davison B, Sexton C and Glaccum M: Active interleukin-1 receptor required for maximal progression of acute pancreatitis. Ann Surg 223 : 163-169 (1996)

15) Norman JG, Fink GW, Messina J, Carter G and Franz MG: Timing of tumor necrosis factor antagonism is critical in determining outcome in murine lethal acute pancreatitis. Surgery 120 : 515-521 (1996)

16) Norman J, Franz M, Messina J, Riker A, Fabri PJ, Rosemurgy AS and Gower WR: Interleukin-1 receptor 
antagonist decreases severity of experimental acute pancreatitis. Surgery 117 : 648-655 (1995)

17) Norman JG, Franz MG, Fink GS, Messina J, Fabri PJ, Gower WR and Carey LC: Decreased mortality of severe acute pancreatitis after proximal cytokine blockade. Ann Surg 221 : 625-634 (1995)

18) Tanaka N, Murata A, Uda K, Toda H, Kato T, Hayashida H, Matsuura N and Mori T : Interleukin-1 receptor antagonist modifies the changes in vital organs induced by acute necrotizing pancreatitis in a rat experimental model. Crit Care Med 23 : 901-908 (1995)

19) Grewal HP, Mohey El-Din AB, Gaber L, Kotb M and Gaber AO: Amelioration of the physiologic and biochemical changes of acute pancreatitis using an anti-TNF polyclonal antibody. Am J Surg 167 : 214-219 (1994)

20) Hughes CB, Grewal HP, Gaber LW, Kotb M, Mohey El-din AB, Mann L and Gaber AO: Anti-TNF $\alpha$ therapy improves survival and ameliorates the pathophysiologic sequelae in acute pancreatitis in the rat. Am J Surg $171: 274-280$ (1996)

21) Yamamoto N, Sakai F, Yamazaki H, Nakahara $K$ and Okuhara M: Effect of FR167653, a cytokine suppressive agent, on endotoxin-induced disseminated intravascular coagulation. Eur J Pharmacol 314 : $137-142$ (1996)

22) Yamamoto N, Sakai F, Yamazaki H, Sato N, Nakahara K and Okuhara M: FR167653, a dual inhibitor of interleukin-1 and tumor necrosis factor- $\alpha$, ameliorates endotoxin-induced shock. Eur J Pharmacol 327 : 169174 (1997)

23) Sano I, Takahashi T, Koji T, Udono H, Yui K and Ayabe H : Prolonged survival of rat cardiac allograft with proinflammatory cytokine inhibitor. $J$ Heart Lung Transplant 20 : 583-589 (2001)

24) Bradley PP, Priebat DA, Christensen RD and Rothstein G: Measurement of cutaneous inflammation: estimation of neutrophil content with an enzyme marker. J Invest Dermatol 78 : 206-209 (1982)

25) Schmidt $G$ and Thannhauser SJ : A method for the determination of deoxyribonucleic acid, ribonucleic acid, and phosphoproteins in animal tissues. J Biol Chem 161 : 83-89 (1945)

26) Schneider WC: Phosphorus compounds in animal tissues; A comparison of methods for the estimation of nucleic acids. J Biol Chem 164 : 747-751 (1946)

27) Burton $\mathrm{K}:$ A study of the conditions and mechanism of the diphenylamine reaction for the colorimetric estimation of deoxyribonucleic acid. Biochem J 62:315-323 (1956)

28) Lowry OH, Rosebrough NJ, Farr AL and Randall RJ : Protein measurement with the Folin phenol reagent. J Biol Chem 193 : 265-275 (1951)

[Received February 5, 2003 : Accepted February 13, 2003] 